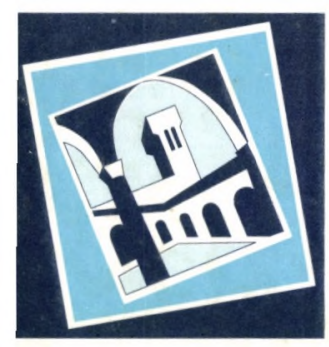

EUROPEAN UNIVERSITY INSTITUTE The Robert Schuman Centre

The De-Facto Transnationalizing of Immigration Policy

\title{
SASKIA SASSEN
}


EUROPEAN UNIVERSITY INSTITUTE

||||||||||||||||||||||||||||||||||||||||||||||||||||||||||||||||||||||||||||||

3 0001002669267 


\section{Jean Monnet Chair Papers}

Sassen: The De-Facto Transnationalizing

of Immigration Policy

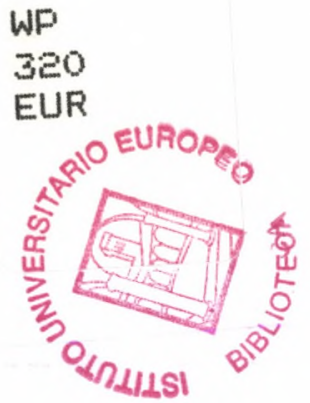




\section{Jean Monnet Chair Papers}

\section{The Jean Monnet Chair}

The Jean Monnet Chair was created in 1988 by decision of the Academic Council of the European University Institute, with the financial support of the European Community. The aim of this initiative was to promote studies and discussion on the problems, internal and external, of European Union following the Single European Act, by associating renowned academics and personalities from the political and economic world to the teaching and research activities of the Institute in Florence. 


\title{
Jean Monnet Chair Papers
}

The De-Facto Transnationalizing of Immigration Policy

\author{
SASKIA SASSEN
}

1996

The Robert Schuman Centre at the European University Institute 
All rights reserved.

No part of this paper may be reproduced in any form without permission of the author.

(C) Saskia Sassen

Printed in Italy in April 1996

European University Institute

Badia Fiesolana

I-50016 San Domenico (FI)

Italy 


\title{
Table of Contents
}

The Border and the Individual as Regulatory Sites

p. 8

Beyond Sovereignty:

Constraints on States' Policy Making

p. 10

Beyond Sovereignty:

Economic Globalization and the Reconfigured State

p. 17

Implications for Immigration Policy

p. 21

\begin{abstract}
Appendix
Going Beyond the Individual:

Economic Internationalization and Geopolitical Linkages
\end{abstract}

p. 25

References

p. 32

Biographical Note

p. 36 
The interaction between the de-nationalizing of key economic institutions and spaces, on the one hand, and the re-nationalizing of politics on the other provides one of the main contexts for immigration policy and practice today. We see a growing consensus in the community of states to lift border controls for the flow of capital, information, services, and more broadly, to further globalization. But when it comes to immigrants and refugees whether in North America, Western Europe or Japan, we see the national state claiming all its old splendor, and asserting its sovereign right to control its borders, a right that is a matter of consensus in the community of states.

What does it mean for the state to relinquish sovereignty in some realms and to continue to be sovereign in others? If we accept, as I do, that the state itself has been transformed by its participation in the implementation of laws and regulations necessary for economic globalization, we must accept as a possibility that sovereignty itself has been transformed. Elsewhere (1996) I have argued that exclusive territoriality - a marking feature of the modern state -- is being destabilized by economic globalization and that we are seeing the elements of a process of denationalization of national territory, though in a highly specialized institutiional and functional way. Further, the particular combination of power and legitimacy we call sovereignty, which has over the last century become almost synonimous with the national state, is today being partly unbundled, redistributed onto other entities, particularly supranational organizations, international agreements on human rights, and the new emergent private international legal regime for business transactions (See Sassen 1996). With all of this happening what does it mean to assert, as is done over and over again in the immigration literature, that the state has exclusive authority over the entry of non-nationals. Is the character of that exclusive authority today the same it was before the current phase of globalization and the ascendance of human rights as a non-state centered form of legitimate power ${ }^{1}$ ?

My analysis focuses largely on immigration in the highly developed receiving countries. I use the notion of immigration policy rather broadly to refer to a wide range of distinct national policies. I should note that it is often difficult

1 Immigration can then be seen as a strategic research site for the examination of the relation and the tension betwen the idea of sovereignty over borders and the constraints states encounter in the design and implementation of actual policy on the matter. 
to distinguish immigrants and refugees. But there is (still) a separate regime for refugees in all these countries. And there is an international regime fot refugees, something that can hardly be said for immigration.

Beyond the first, brief introductory section, I will focus first on the con straints faced by the state in highly developed countries in the making of im: migration policy today, and then on the constraints resulting from the state role in the implementation of global economic processes and institutions. I the final section I discuss the implications of these two types of constraints for immigration policy making and implementation.

\section{The Border and the Individual as Regulatory Sites}

In my reading there is a fundamental framework that roots all the country specific immigration policies of the developed world in a common set of c@n ceptions about the role of the state and of national borders. The purpose here is not to minimize the many differences in national policies, but to underlines the growing convergence in various aspects of immigration policy and prace tice $^{2}$.

First, the sovereignty of the state and border control, whether land borders airports, or consulates in sending countries, lie at the heart of the regulatere effort. Secondly, immigration policy is shaped by an understanding of immiev gration as the consequence of the individual actions of emigrants; the receiving country is taken as a passive agent, one not implicated in the process of emi gration. In refugee policy, in contrast, there is a recognition of other factorsbeyond the control of individuals, as leading to outflows ${ }^{3}$. Two fundmenta

2 There is a vast and rich scholarly literature that documents and interprets the specificity and distinctiveness of immigration policy in highly developed countries (e.g. Weil 1991, Cornelius, Hollifield and Martin 1994; Weiner 1995; Soysal 1994; Thranhardt 1993; Bade 1992 , to mention just a few). As a body this literature allows us to see the many differences among these countries.

3 Refugee policy in some countries does lift the burden of immigration from the immigrant' shoulders. US refugee policy, particularly for the case of Indochinese refugees, does? acknowledge partial responsibility on the part of the government. Clearly, in the case of economic migrations, such responsibility is far more difficult to establish, and by its nature far more indirect. 
traits of immigration policy are, then, that it singles out the border and the individual as the sites for regulatory enforcement.

The sovereignty of the state when it comes to power over entry is well established by treaty law and constitutionally. The Convention of The Hague of 1930 asserted the right of the state to grant citizenship; the 1952 Convention on Refugees which asserted that the right to leave is a universal right, remained silent on the right to entry - better silence than evident contradiction. (As is well known, the status of refugees and their right not to be forcibly returned are established in international law, but there is no corresponding right of asylum; such right is at the discretion of a receiving state). There are various human rights declarations and conventions that urge states to grant asylum on humanitarian grounds, but they all recognize the absolute discretion of states in this matter ${ }^{4}$. A few states, notably Austria and Germany, give those formally recognized as refugees a legal right to asylum - though this is under revision. More recently, the various agreements towards the formation of the European Union, keep asserting the right of the state to control who can enter. This is quite a contrast with the assertions in the GATT, NAFTA, and the EU about the need to lift state controls over borders when it comes to the flow of capital, information, services, and state controls over the domestic financial markets.

Secondly, on the matter of the individual as a site for enforcement, two different operational logics are becoming evident. One of these logics - the one embedded in immigration policy - places exclusive responsibility for the immigration process on the individual, and hence makes of the individual the site for the excercise of the state's authority. There is a strong tendency in immigration policy in developed countries to reduce the process to the actions of individuals. The individual is the site for accountability and for enforcement. Yet it is now increasingly being recognized that international migrations are embedded in larger geopolitical and transnational economic dynamics. The worldwide evidence shows rather clearly that there is considerable patterning in the geography of migrations, and that the major receiving countries tend to get immigrants from their zones of influence. This holds for countries as diverse as the US, France or Japan. Immigration is at least partly an outcome of the actions of the governments and major private economic actors in receiving countries. Economic internationalization and the geopolitics resulting from

4 One important exception is The 1969 Convention on Refugee Problems in Africa adopted by the Organization of African States which includes the right to entry. 
older colonial patterns suggest that the responsibility for immigration may not be exclusively the immigrant's. Analytically these conditions only can enter into theorizations about the state and immigration when we suspend the proposition implicit in much immigration analysis, that immigration is the result of individual action. (Given the wider familiarity with this subject, $E_{5}$ have confined it to the Appendix in this paper). In the other logic, that embedded in human rights agreements, the individual emerges as a site form

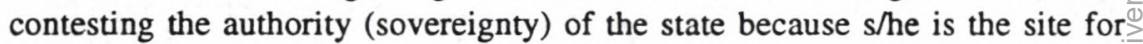
human rights. (For a detailed analysis of the interaction of these two logics see Sassen 1996).

The next section examines the constraints within which the state in the highly developed countries makes immigration policy.

\section{Beyond Sovereignty: Constraints on States' Policy Making}

When it comes to immigration policy, states under the rule of law increasingly confront a range of rights and obligations, pressures from both inside and outside, from universal human rights to not so universal ethnic lobbies. The overall effect is to constrain the sovereignty of the state and to undermine old notions about immigration control.

First, we see emerging a de facto regime, centered in international agreements and conventions as well as in various rights gained by immigrants, that limits the state's role in controlling immigration. An example of such an agreementis the International Convention adopted by the General Assembly of the UN on Dec. 181990 on the protection of the rights of all migrant workers and members of their families (Resolution 45/158). (See, e.g. Hollifield, 1992; Baubock 1994; Sassen 1996, Part Three). Further, there is a set of rights of residento immigrants widely upheld by legal authorities. We have also seen the gradual expansion over the last three decades of civil and social rights to marginal populations, whether women, ethnic minorities, or immigrants and refugees.

The extension of rights, which has taken place mostly through the judiciary has confronted states with a number of constraints in the area of immigration and refugee policy. For instance, there have been attempts by the legislature in 
France and Germany to limit family reunification which were blocked by administrative and constitutional courts on the grounds that such restrictions would violate international agreements. The courts have also regularly supported a combination of rights of resident immigrants which have the effect of limiting the government's power over resident immigrants. Similarly such courts have limited the ability of governments to restrict or stop asylum seekers from entering the country5.

Finally, the numbers and kinds of political actors involved in immigration policy debates and policy making in Western Europe, North America, and Japan are far greater than they were two decades ago: the European Union, anti-immigrant parties, vast networks of organizations in both Europe and North America that often represent immigrants, or claim to do so, and fight for immigrant rights, immigrant associations and immigrant politicians, mostly in the second generation, and, especially in the US so-called ethnic lobbies ${ }^{6}$. The policy process for immigration is no longer confined to a narrow governmental arena of ministerial and administrative interaction. Public opinion and public political debate have become part of the arena wherein immigration policy is shaped? ${ }^{7}$. Whole parties position themselves politically in

5 These efforts that mix the conventions on universal human rights and national judiciaries assume many different forms. Some of the instances in the US are the sanctuary movement in the 1980 s which sought to establish protected areas, typically in churches, for refugees from Central America; judicial battles, such as those around the status of Salvadoreans granted indefinite stays though formally defined as illegal; the fight for the rights of detained Haitians in an earlier wave of boat lifts. It is clear that notwithstanding the lack of an enforcement apparatus, human rights limit the discretion of states in how they treat nonnationals on their territory. It is also worth noting in this regard that UNHCR is the only UN agency with a universally conceded right of access to a country.

While these developments are well known for the cases of Europe and North America, there is not much general awareness of the fact that we are seeing incipient forms in Japan as well (See, e.g. Shank 1995). For instance in Japan today we see a strong group of human rights advocates for immigrants; efforts by non-official unions to organize undocumented immigrant workers; organizations working on behalf of immigrants which receive funding from individuals or government institutions in sending countries (e.g. the Thai Ambassador to Japan announced in October 1995 that his government will give a total of 2.5 million baht, about 100,000 US\$, to five civic groups that assist Thai migrant workers, especially undocumented ones; see Japan Times, October 18 1995).

7 Further, the growth of immigration, refugee flows, ethnicity and regionalism, raise questions about the accepted notion of citizenship in contemporary nation-states and hence about the formal structures for accountability. My research on the international circulation of capital and labor has raised questions for me on the meaning of such concepts as national economy and national workforce under conditions of growing internationalization of capital and the growing presence of immigrant workers in major industrial countries. Furthermore, the rise of ethnicity in the US and in Europe among a mobile work-force raises questions 
terms of their stand on immigration, especially in some of the European countries.

These developments are particularly evident in the case of the European Union ${ }^{8}$. Europe's single market program has had a powerful impact in raising the prominence of various issues associated with free circulation of people as an essential element in creating a frontier-free community; the EC institutions lacked the legal competence to deal with many of these issues but had to begin to address them. Gradually EC institutions have wound up more deeply involved with visa policy, family reunification and migration policy - all formerly exclusively in the domain of the individual national states. National gov-o ernments resisted EC involvement in these once exclusively national domains. But now both legal and practical issues have made such involvement acceptabe and inevitable notwithstanding many public pronouncements to the contrary

It is becoming evident that many aspects of immigration and refugee poliey intersect with EC legal competence. A key nexus here is the free movement fon persons and attendant social rights as part of the formation of a single market. In practice the $\mathrm{EC}$ is assuming an increasingly important role and the fact thit these are immigration countries is slowly being acknowledged. The monetary and economic union would require greater flexibility in movement of workers and their families and thereby pose increasing problems for national immigration laws regarding non-Ec nationals in $\mathrm{EC}$ member states.

There is now growing recognition for the need of an EC-wide immigration policy, something denied for a long time by individual states. This has become? even more urgent with the collapse of the socialist bloc, and the rapid increase in refugees. Though very slowly the general direction has been towards a closer union of member states immigration policies.

In the case of the US, the combination of forces at the governmental level is quite different yet has similar general implications about the state's constraints

about the content of the concept of nation-based citizenship. The portability of national identity raises questions about the bonds with other countries, or localities within them; and the resurgence of ethnic regionalism creates barriers to the political incorporation of new immigrants.(See, e.g. Soysal, 1995; Baubock, 1994; Sassen 1996a).

8 There is a large and rich literature on the development of immigration policy at the European level; please refer to footnote for a few citations. Longer bibliographies and analyses on the particular angle under discussion here - limitations on the autonomy of the state in making immigration policy - can also be found in Sassen 1996; in progress). 
in immigration policy making. Immigration policy in the US is today largely debated and shaped by Congress, and hence is highly public and subject to a vast multiplicty of local interests, notably ethnic lobbies ${ }^{9}$. And we know well how very sensitive congressmen and women are to the demographics of their districts. This has made it a very public process, quite different from other processes of policy making 10 .

The fact that immigration in the US has historically been the preserve of the Federal government, particularly Congress, assumes new meaning in today's context of radical devolution - the return of powers to the states ${ }^{11}$. There is now an emerging conflict between several state governments and the Federal government around the particular issue of federal mandates concerning immigrants - such as access to public health care and schools - without mandatory federal funding. Thus states with disproportionate shares of immigrants are asserting that they are disproportionately burdened by the putative

9 Jusrisdiction over immigration matters in the US Congress lies with the Judiciary Committee, not with the Foreign Affairs Commitee as might have been the case. Congressional intent on immigration is often at odds with the foreign affairs priorities of the Executive. There is a certain policy making tug of war (Mitchell, 199 ). It has not always been this way. In the late 1940s and 1950s there was great concern with how immigration policy could be used to advance foreign policy objectives. The history of what government agency was responsible for immigration is rather interesting. Earlier, when the Department of Labor (DOL) was created in 1914 it got the responsibility for immigration policy. On June 1933, President Roosevelt combined functions into the Immigration and Naturalization Service within DOL. The advent of WWII brought a shift in the administrative responsibility for the country's immigration policy: in 1940 President Roosevelt recommended it be shifted to the Department of Justice, because of the supposed political threat represented by immigrants from enemy countries. This was meant to last for the war and then INS was to be returned to the DOL. But it never was. It also meant that immigration wound up in Congress in committees traditionally reserved for lawyers, as are the Senate and House Judiciary Committees. It has been said that this is why immigration law is so complicated (and, I would add, so centered on the legalities of entry and so unconcerned with broader issues).

10 There are diverse social forces shaping the role of the state depending on the matter at hand. Thus in the early 1980s bank crisis, for instance, the players were few and well coordinated; the state basically relinquished the organizing capacity to the banks, the IMF, and a few other actors. All very discreet, indeed so discreet that if you look closely the government was hardly a player in that crisis. This is quite a contrast with the deliberations around the passing of the 1986 Immigration and Reform Control Act - which was a sort of national brawl. In trade liberalization discussions there are often multiple players, and the executive may or may not relinquish powers to congress.

11 Aman Jr. (1995) has noted that although political and constitutional arguments for reallocating federal power to the states are not new, the recent re-emergence of the Tenth Amendment as a politically viable and popular guideline is a major political shift since the New Deal in the relations between the federal government and the states. 
costs of immigration. I should note, that in the US the costs of immigration are an area of great debate and wide ranging estimates ${ }^{12}$. At the heart of this conflict is the fact that the Federal Government sets policy but does not assumer responsibility, financial or otherwise for the implementation of many key aspects of immigration policy. The conflict is illustrated by the notorious case of the state of California and its US\$ 377 million lawsuit against the Federa! government. The radical devolution under way now is going to accentuate some of these divisions further.

One of the questions raised by these developments concerns the nature of the control by the state in regulating immigration? The question here is not sos much, how effective is a state's control over its borders - we know it is never absolute. The question concerns rather the substantive nature of state control over immigration given international human rights agreements, the extension of various social and political rights to resident immigrants over the last twenty years, the multiplication of political actors involved with the immigtation question.

There is, first, the matter of the unintended consequences of policiess, wheter immigration policies as such or other kinds of policies which hayes immigration impacts. For instance, the 1965 US Immigration Act had consequences not intended or foreseen by its framers (Reimers, 1983; Briggs 1994), there was a generalized expectation it would bring in more of the nationalities already present in the country, i.e. Europeans, given its emphasis on faminy reunion. Other kinds of unintended consequences are related to the interna tionalization of production and foreign aid (Sassen 1988; Journal fur Entwick lungspolitik 1995; Bonacich et al. 1995). These often turned out to have unexpected impacts on immigration. Similar unintended consequences have been associated with military aid and subsequent refugee flows, e.g. Salvador in the decade of the 1980s (Mahler 1995). Although immigration policy has rarely been an explicit, formal component of foreign policy apparatus in the US, the latter has had significant impacts on immigration besides the weel established fact of refugee flows from Indochina. If one were to be discreet, one would say that foreign aid has rarely deterred emigration ${ }^{13}$. It is also a fact that

12 The latest study by the Washington based Urban Institute found that immigrants contribute US $\$ 30$ billion more in taxes than they take in services.

13 Take Salvador in the 1980s: billions of dollars in aid poured in, and hundreds of thousands of Salvadorans poured out as US aid raised the effectiveness of Salvador's military control and aggression against its own people. Or the case of the Philippines, a country that received massive aid and has had high emigration. In both cases it was foreign aid dictated 
domestic US policies with a foreign, overseas impact have contributed to promote emigration to the US. There is the notorious sugar price support provision of the early 1980s: tax payers paid 3 billion annually to support the price of sugar for US producers. This kept Caribbean Basin countries out of the competition and resulted in a loss of 400,000 jobs there from 1982 to 1988; for example, the Dominican Republic lost three quarters of its sugar export quota in less than a decade. The 1980s was also an era of large increases in immigration from that region.

A second type of condition that illuminates the issue of the substantive nature of the control by states over immigration is a twist on the zero sum argument. If a government closes one kind of entry category, recent history shows that another one will have a rise in numbers. A variant on this dynamic is that if a government has, for instance, a very liberal policy on asylum, public opinion may turn against all asylum seekers and close up the country totally; this in turn is likely to promote an increase in irregular entries ${ }^{14}$.

There is a third set of conditions that can be seen as reducing the autonomy of the state in controlling immigration. Large scale international migrations are embedded in rather complex economic, social and ethnic networks. They are highly conditionned and structured flows. States may insist in treating immigration as the aggregate outcome of individual actions and as distinct and autonomous from other major geopolitical and transnational processes. But they cannot escape the consequences of those larger dynamics and of their insistence on isolating the immigration policy question.

These constraints on the state's capacity to control immigration should not be seen as a control crisis. This type of analysis opens up the immigration policy question beyond the familiar range of the border and the individual as

by security issues. Emigration resulting from US economic and political interventions is evident in the Dominican emigration in the 1960s and in the emigration from India and Pakistan to the US - the latter two associated as well with security aid from the US. (I have long argued as a scholar that policy makers should have migration impact statements attached to various policies.)

14 Increasingly, unilateral policy by a major immigration country is problematic. One of the dramatic examples was that of Germany which began to receive massive numbers of entrants as the other European states gradually tightened their policies and Germany kept its very liberal asylum policy. Another case is the importance for the EC today that the Mediterranean countries - Italy, Spain and Portugal - control their borders regarding nonEC entrants. 
the sites for regulatory enforcement. It signals that international migrations are partly embedded in conditions produced by economic internationalization both in sending and in receiving areas. While a national state may have the power to write the text of an immigration policy, it is likely to be dealing with a complex, deeply embedded and transnational process that it can only partly address or regulate through immigration policy as conventionally understood 15 .

While the state continues to play the most important role in immigration policy making and implementation, the state itself has been transformed by the growth of a global economic system and other transnational processes. These have brought yet another set of conditions to bear on the state's regulatory role. One particular aspect of this development is of significance to the role of the state in immigration policy making and implementation: The state in all the highly developed countries (and in many of the developing countries) has par ticipated in the implementation of a global economic system and in furthering a consensus around the pursuit of this objective. This participation has transformed the state itself, affected the power of different agencies within it, and it has furthered the internationalization of the inter-state system. It is thus $\mathrm{n}$ g longer sufficient simply to examine the role of the state in migration policy design and implementation; it is necessary to examine also the transformation of the state itself and what that can entail for migration policy and the regula tion of migration flows and settlement. For the purposes of immigration po? icy analyses it is becoming important to factor in these transformations of the state and the inter-state system precisely because the state is a major actor in immigration policy and regulation. This transformation of the state and the inter-state system is the subject of the next section.

15 On a somewhat related matter, it seems to me that the sense of an immigration control crisis that prevails today in many of the highly developed countries is in some ways unwarranted, even though states have less control than they would like because immigration is caught in a web of other dynamics. When we look at the characteristics of immigrations over time and across the world, it is clear that these are highly patterned flows, embedded in other dynamics which contain equilibrating mechanisms, that they have a duration (many immigrations have lasted for fifty years and then come to an end); that there is more return migration than we generally realize (e.g. soviet engineers and intellectuals who went back to Moscow from Israel; Mexicans who returned after becoming legal residents through the IRCA amnesty program, feeling that now they could circulate between the two countries); we also know from earlier historical periods when there were no controls, that most people did not leave poorer areas to go to richer ones, even though there were plenty of such differences in Europe within somewhat reasonable travel distances (Sassen 1996a; in progress). 


\section{Beyond Sovereignty: Economic Globalization and the Reconfigured State}

A very different set of obligations limiting the autonomy of the state in policy making arises from the emerging consensus in the community of states to support free trade, deregulation of the domestic financial markets, and open borders for the circulation of capital and information.

Globalization and deregulation have reduced the role of the state in the governance of economic processes ${ }^{16}$. But the state remains as the ultimate guarantor of the rights of capital whether national or foreign17. Firms operating transnationally want to ensure the functions traditionally exercised by the state in the national realm of the economy, notably guaranteeing property rights and contracts. The state here can be conceived of as representing a technical administrative capacity which cannot be replicated at this time by any other institutional arrangement (Sassen, 1996); furthermore, this is a capacity backed by military power. In pursuing this, state has been changed. The structure of the state itself in developed countries has undergone a shift away from those agencies most closely tied to domestic social forces as was the case

16 Globalization has contributed to a massive push towards deregulation across the board in many of the highly developed countries. Aman, Jr. (1995) notes that though not all industries in a nation are equally subject to intense global competition, the existence of such competition in general contributes to an overall political context that encourages domestic regulatory reform in all industries. "Political movements and regulatory trends do not tend to discriminate among industries once the momentum for certain reforms is underway" (Aman, Jr. 1995: 433). The impact of global competition on the domestic politics of regulation goes well beyond the industries in which this competition is most intense. For some recent formulations in what is a vast literature see Bonacich et al., 1994; Social Justice 1993; Bose and Acosta-Belen 1995).

17 This guarantee of the rights of capital is embedded in a certain type of state, a certain conception of the rights of capital, and a certain type of international legal regime: largely the state of the most developed and most powerful countries in the world, western notions of contract and property rights, and a new legal regime aimed at furthering economic globalization. The hegemony of neo-liberal concepts of economic relations with its strong emphasis on markets, deregulation, free international trade has influenced policy in the 1980s in USA and UK and now increasingly also in continental Europe. This has contributed to the formation of transnational legal regimes that are centered in Western economic concepts. Through the IMF and IBRD as well as Gatt this vision has spread to the developing world. An issue that is emerging as significant in view of the spread of western legal concepts is the critical examination of the philosophical premises about authorship and property that define the legal arena in the West (e.g. Coombe, 1993.) 
in the US during the Pax Americana and towards those closest to the transnational process of consensus formation 18 .

There has also been a displacement of public functions that were once in the domain of the government on to non- and quasi-governmental institutions 19 , The formation of the WTO represents such a displacement compared with earlier arrangements such as those of the Pax Americana. In the US, such a displacement is perhaps most sharply evident in the growing weight of its central bank in the setting of national economic policy. In its decisions the Federal Reserve, a body that prides itself for its independence from the gov- $\subseteq$ ernment, is sharply influenced by the financial markets, which are increasingly international; and national economic policy in the US is increasingly being set by the Federal Reserve and the financial markets 20 .

18 According to some (see Panitch 1996; Mittelman 1996; Drache and Gertler 1991) the neoliberalism of the 1980 s has redefined the role of states in national economies and in the inter-state system.

19 There are various sites for governance in the world economy beyond the nation-state Among these are organizations involved with international economic issues, from the International Chamber of Commerce and the Court of Justice at The Hague, to the documents for, and authorized committees working on, the Single European Market and the free trade agreement between the US, Canada and Mexico. These are all de facto engaged in identifying, formalizing, and redesigning, components of transnational systems for economic governance.

20 The extent to which the international financial markets are dictating economic policy for rich and poor countries was well illustrated with the case of the Mexico financial crisis and the subsequent fear in Argentina and Brazil that they might "lose the confidence of the international financial markets." The extent to which the US government is being shaped by the international financial markets in its economic decisions was illustrated by the priority given to a rescue package for the Mexican financial crisis and by the type of solution contained in this package, to wit, the restoration of the confidence of the international financial markets in Mexico, specifically, in investment opportunities in Mexico. A financial response to this crisis was but one of several potential choices. For instance, conceivably there could have been an emphasis on promoting manufacturing growth and protecting small businesses and small homeowners from the bankruptcies now faced by many. And the US government could also conceivably have exhorted the Mexican government to give up on restoring confidence in the global financial markets and to focus on the production of real value added in the Mexican economy. Furthermore, this matter, which was basically presented as a global economic security issue, was handled not by the Secretary of State, but by the Secretary of the Treasury, someone who had been the so-called "Dean" of Wall Street. There are two rather important novel elements here: that Treasury should handle this international crisis, and that the Secretary of that agency was a former top partner at Goldman Sachs Securities on Wall Street, one of the leading global financial firms. The point for me here is not the potential for comuption but rather a question of an optic on what is desirable economically. 
Another instantiation of this transformation concerns the impact of today's global economy on the inter-state system. More generally, economic internationalization can, in principle, have different types of impacts or consequences for the inter-state system. During the Pax Americana, the effect was to strengthen the inter-state system. Leading economic sectors, especially manufacturing and raw materials extraction, were subject to international trade regimes that contributed to build the inter-state system. Individual states adjusted national economic policies to further this type of international economic system, doubtless often pressured by the hegemonic power of the US.(Even though already then certain sectors did not fit comfortably under this largely trade dominated inter-state regime: out of their escape emerged the euro-markets and off-shore tax havens of the 1960s).

The evolution of international finance and the corporate services sector brings to the fore the extent to which the forms of economic globalization evident in the last two decades have not necessarily had the effect of strengthening the inter-state system ${ }^{21}$. The ascendance of international finance has produced regulatory voids that lie beyond not only states but also the inter-state system 22 . Existing systems of governance and accountability for transnational economic activities and entities leave much ungoverned when it comes to these industries 23 .

21 There is an enormous literature on how the evolution of international finance over the 1980s reduced the regulatory control excercised by the state over this industry (For a discussion and review of this literature see Sassen, 1991: Part Two). This literature has to a large extent focused on the loss of regulatory power by single states. It has not addressed the question as to the impact on the inter-state system.

22 Because they are deeply embedded in telematics, advanced information industries also shed light on questions of control in the global economy that not only go beyond the state and the inter-state system but also beyond the notions of non-state centered systems of coordination prevalent in the literature on governance. These are questions of control that have to do with the orders of magnitude that can be achieved in the financial markets thanks to the speed in transactions made possible by the new technologies. The best example is probably the foreign currency markets which operate largely in electronic space and have achieved volumes that have left the central banks incapable of exercising the influence on exchange rates they are expected to have. These are questions of control that arise out of the properties of the new information technologies, notably the immense speed-up of transactions they make possible, rather than out of the extension of the economy beyond the state.(See Sassen 1996)

23 In this regard, an analysis of these industries sharpens the differences between the role of the state in earlier forms of internationalization and the current globalization of economic activity evident in some, though by no means all economic sectors. 
The deregulation of key operations and markets in the financial industry can be seen as a negotiation between nation-based legal regimes and the formation of a consensus among a growing number of states about furthering the world economy (Mittelman, 1996; Trubek et al., 1993). In other words, it is not simply a matter of a space economy extending beyond a national realm ${ }^{24}$. It also has to do with the formation and legitimation of transnational legal regimes that are operating in national territories. National legal fields are becoming more internationalized in some of the major developed economies and transnational legal regimes are becoming more important and begin to penetrate national fields hitherto closed (e.g., Trubek et al.1993)25.

There are other instances of a displacement of what were once government functions for economic governance onto non- or quasi-governmental entities. Among the most important ones in the private sector today are international commercial arbitration and the variety of institutions which fulfill rating and avisory functions that have become essential for the operation of the global economy. Over the past 20 years, international commercial arbitration has been transformed and institutionalized as the leading contractual method for the resolution of transnational commercial disputes. (Dezalay and Garth, 1995; Aksen, 1990). In a major study on international commercial arbitration (summarized in Dezalay and Garth 1995) Dezalay and Garth conclude that itus a delocalized and decentralized market for the administration of international commercial disputes, connected by more or less powerful institutions as d individuals who are both competitive and complementary.

Another instance of a private regulatory system is represented by debt security or bond rating agencies which have come to play an increasingly important role in the global economy. In his study of credit rating processes, Sinclair (1994) found that these agencies function as mechanisms of

24 We are seeing the formation of an economic complex (finance and corporate services) with properties clearly distinguishing it from other economic complexes in that the articulation of its valorization dynamic with the public economic functions of the state is quite weak compared with Fordist manufacturing, for example. That is to say, it needs the state much less than Fordist manufacturing did.

25 Globalization restricts the range of regulatory options of national governments, as the Mexico crisis illustrates. Aman, Jr. (1995) shows how a global perspective on domestic regulatory politics helps explain the absence of radical differences in the regulatory outcomes of different US administrations over the last fifteen years. The pressures of global competition, the nature of corporate entities involved, and domestic political pressures to minimize costs and maximize flexibility militate in favor of new, more market-oriented forms of regulatory reform. 
'governance without government.' He found that they have leverage because of their distinct gate-keeping functions with regard to investment funds sought by corporations and governements. Sinclair (1994) posits that in this regard they can be seen as a significant force in the operation and expansion of the global economy. As with business law, the US agencies have expanded their influece overseas. (See generally Salacuse 1991; Aksen 1990). Sinclair (1994: 150) notes that ten years ago Moody's and Standard and Poor had no analysts outside the US; by 1993 they each had about 100 in Europe, Japan and Australia.

Among the main points to extract from this examination are the changed articulation of the public functions of the state with major economic sectors and the displacement of what were once governmental functions on to non- or quasi-governmental entities.

There are two distinct issues here. One is the formation of new legal regimes that negotiate between national sovereignty and the transnational practices of corporate economic actors. The second issue is the particular content of this new regime, one which contributes to strengthen the advantages of certain types of economic actors and to weaken those of others. That is to say, one could posit two distinct issues regarding governance: one centered on the effort to create viable systems of coordination/order among the powerful economic actors now operating globally, such as international commercial arbitration and credit rating agencies discussed in the previous section. A second issue is not so much focused on how to create order at the top but on equity and distributive questions in the context of a globally integrated economic system with immense inequalities in the profit-making capacities of firms and in the earnings capacities of households. It is in this second context that the question of immigration is partly ensconced (Sassen 1996, Part three).

\section{Implications for Immigration Policy}

Does current immigration policy in advanced receiving economies need to factor-in these transformations if it is to be reasonably effective? There is some consensus about the fact of a growing gap between immigration policy intent and immigration reality in the major developed receiving countries (e.g. Cornelius, Hollifield and Martin 1995). One possibility is that the rather low level of effectiveness of migration policy today is partly due to its neglect of 
these transformations in the larger context for international migration and in the institutional apparatus for its regulation; migration policy continues to be characterized by its formal isolation from other major processes, as if it were possible to handle migration as a bounded, closed event.

Today we can see in all highly developed countries a combination of drives to create border-free economic spaces and drives for renewed border-control to keep immigrants and refugees out. The juxtaposition between these two dynamics provides one of the principal contexts in which today's efforts to stop immigration assume their distinct meaning.

Current immigration policy in developed countries is increasingly at odds with other major policy frameworks in the international system and with the growth of global economic integration. There are one could say, two major epistemic communities--one concerning the flow of capital and information; the other, immigration. Both of these epistemic communities are internationat, and both enjoyg widespread consensus in the community of states.

The coexistence of such different regimes for capital and for immigrants has not been seen as an issue in the US The case of the EU is of interest here because it represents an advanced stage of formalization, and in this effort European states are discovering the difficulties if not impossibility of main tainng two such diverse regimes. The European Community and the nationa governments of member states have found the juxtaposition of the diverge regimes for immigration flows and for other types of flows rather difficult to handle. The discussion, design and implementation of policy aimed at forming a European Union make it evident that immigration policy has to account the facts of rapid economic internationalization. The European Union shows us with great clarity the moment when states need to confront this contradiction in their design of formal policy frameworks. The other major regional systems in the world are far from that moment and may never reach it. Yet they contain less formalized versions of the juxtaposition between border-free economies and border controls to keep immigrants out. NAFTA is one such instance, as are, in a more diffuse way, various initiatives for greater economic integration in the Western Hemisphere.

Though less clearly than in Western Europe, these issues are present in other regions with cross-border migrations. These are regional systems constituted partly as zones of influence of major economic or geo-political powers, e.g. the long term dominance of the US over the Caribbean Basin. What 
matters here is that to a good extent major international migration flows have been embedded in some or another variant of these regional systems. The quasi-transnational economic integration characterizing such regional systems produces its own variety of contradictions between drives for border-free economic spaces and border-control to keep immigrants and refugees out.

There are strategic sites where it becomes clear that the existence of two very different regimes for the circulation of capital and the circulation of immigrants poses problems that cannot be solved through the old rules of the game, where the facts of transnationalization weigh in on the state's decisions regarding immigration. For instance, the need to create special regimes for the circulation of service workers both within GATT and NAFTA as part of the further internationalization of trade and investment in services (see Sassen, in progress). This regime for the circulation of service workers has been uncoupled from any notion of migration; but it represents in fact a version of temporary labor migration. It is a regime for labor mobility which is in good part under the oversight of entitites that are quite autonomous from the government ${ }^{26}$. This points to an institutional reshuffling of some of the components of sovereign power over entry and can be seen as an extension of the general set of processes whereby state sovereignty is partly being decentered onto other non- or quasi-governmental entities for the governance of the global economy (Sassen 1996).

All of these developments have the effect of a) reducing the autonomy of the state in immigration policy making; and b) multiplying the sectors within the state that are addressing immigration policy and therewith multiplying the room for conflicts within the state. The assertion that the state is in charge of immigration policy is less and less helpful. Policy making regarding international issues can engage very different parts of the government. The state itself has not only been transformed by its participation in the global economy, but has of course never been a homogeneous actor. It is constituted through multiple agencies and social forces. Indeed it could be said (cf. Mitchell 199 ) that

26 Another instantiation of the impact of globalization on governmental policy making can be seen in Japan's new Immigration law passed in 1990 (actually an amendment on an earlier law on the entry and exit of aliens). This legislation opened the country to several categories of highly specialized professionals with a western background (e.g. experts in international finance, in western-style accounting, in western medicine, etc) in recognition of the growing internationalization of the professional world in Japan; it made the entry of what is referred to as "simple labor" illegal (Sassen 1993). This can be read as importing "western human capital" and closing borders to immigrants. 
although the state has central control over immigration policy, the work of excercising that claimed power often begins with a limited contest between the state and interested social forces. These interest groups include agribusiness, manufacturing, humanitarian groups, unions, ethnic organizations, zero population growth efforts. Today we need to add to this the fact that the hierarchies of power and influence within the state are being reconfigured by the furthering of economic globalization 27 .

The conditions within which immigration policy is being made and implemented today range from the pressures of economic globalization and its implications for the role of the state to international agreements on human rights. And the institutional setting within which immigration policy is being made and implemented ranges from national states and local states to supranational organizations.

Why does this transformation of the state and the inter-state system matter for immigration? The displacement of governance functions away from the state to non-state entities affects the state's capacity to control or keep contro! ling its borders. New systems of governance are being created. Increasing they may create conflicts with the state's capacity to keep on regulating immigration in the same ways. Further, the transformation of the state itself through its role in the implementation of global processes, may well contribute to new constraints, options and vested interests. The ascendance of agencies linked to furthering globalization and the decline of those linked to domestis equity questions is quite likely to eventually have an effect on the immigration agenda.

27 For instance, an item on internal changes in the state which may have impacts on immigration policy is the ascendance of so-called soft security issues. According to some observers, recent government reorganization in the departments of State, Defense, and the CIA reflects an implicit redefintiion of national security. 


\section{Appendix}

\section{Going Beyond the Individual: Economic Internationalization and Geopolitical Linkages}

Each country is unique and each migration flow is produced by specific conditions in time and place. But if we are to theorize the impact of economic internationalization we need to abstract from these particularities so as to examine more general tendencies in economic dominance and the formation of transnational spaces for economic activity. The purpose would be to capture the impact of the internationalization of economies on a) the formation of mechanisms binding emigration and immigration countries, and b) the organization of labor markets in both types of countries.

The assumption is that these developments in turn have an impact on the formation and directionality of migration flows. They produce conditions under which poverty, unemployment or lack of opportunities for advancement can become activated as migration push factors, e.g. the development of commercial agriculture and of export oriented standardized manufacturing have dislocated traditional economies and eliminated survival opportunities of small producers. And they contribute to the conditions under which immigrants can become incorporated in the labor markets of receiving countries, e.g. increased competitive pressures due to the internationalization of production have contributed to the weaken unions and generally to the search of low-wage workers in order to remain competitive with cheap third world imports.

The mechanisms binding immigration countries to emigration countries can, in principle assume many forms. But two appear to be dominant and account for most of the formation of flows. One is past colonial and current neo- or quasi-colonial bonds, including the types of military presence the US has taken in such diverse situations as El Salvador or Philippines. The other is the range of economic linkages brought about by economic internationalization, ranging from the off-shoring of production, the implantation of export-oriented agriculture through foreign investment, to the weight of multinationals in the consumer markets of sending countries. There is a third type of linkage, characterized by far higher degrees of specificity and including a variety of mechanisms: the organized recruitment of workers, either directly by the government, in the framework of a government supported initiative by employers, or 
through kinship and family networks. Ethnic linkages established between communities of origin and destination, typically via the formation of transnational households or broader kinship structures, emerge as crucial once a flow has been formed and serve to ensure its reproduction over time. These recruitment and ethnic linkages tend to operate within the broader transnational spaces constituted via neo-colonial processes and/or economic internationalization.

Some form of organized recruitment by employers or governments on behalf of employers often lies at the origin of immigration flows, both in the 1800 s and today. But eventually most migration flows gain a certain autonomy from the organized recruitment mechanisms. While organized recruitment, and therewith the constitution of certain countries as labor-exporting couñtries, is in many ways radically different from the migrations engendered ty erstwhile colonial bonds, there are also similarities 28 .

The large mass migrations of the 1800 s emerged as part of the formation a trans-Atlantic economic system binding several nation-states through economic transactions and wars. The trans-Atlantic economy was at the core of US development. There were massive flows of capital, goods and workers and specific structures that produced this trans-Atlantic system. Before this period, labor movements across the Atlantic had been largely forced, notably slavery, and mostly from colonized African and Asian territories. Similarly, the migrations to England in the 1950s originated in what had once been British territories. Finally, the migrations into Western Europe of the 1960s and 1970 s occurred in a context of direct recruitment and of European regional dominance over the mediterranean and over some of the Eastern European countries. There are, I would say, few if any innocent bystanders among countries receiving large labor migrations. Receiving countries have typically been participants in the processes leading to the formation of international migration.

28 In many ways the labor-exporting country is put in a subordinate position, and keeps being represented in the media and in political discourse as a labor-exporting country. This was also the case last century when some labor-sending areas existed in conditions of economic subordination and often also quasipolitical subordnination. The former Polish territories partioned off to Germany were such a region, a region which generated significant migration of "ethnic" Poles to Western Germany and beyond. It is the case of the Irish in England; and of Italy, which kept reproducing itself as a labor supplier for the rest of Europe. 
The renewal of mass immigration into the US in the 1960s, after five decades of little or no immigration, took place in a context of expanded US economic and military activity in Asia and the Caribbean Basin. The United States is at the heart of an international system of investment and production that binds these various regions. In the 1960s and 1970s, the United States played a crucial role in the development of a world economic system. It passed legislation aimed at opening its own and other countries' economies to the flow of capital, goods, services and information. This central military, political and economic role contributed, I argue, both to the creation of conditions that mobilized people into migrations, whether local or international, and to the formation of links with the United States that subsequently were to serve as often unintended bridges for international migration. Measures commonly thought to deter emigration - foreign investment and the promotion of exportoriented growth in developing countries - seem to have had precisely the opposite effect. Among the leading senders of immigrants to the United States in the 1970s and 1980s have been several of the newly industrialized countries of South and Southeast Asia whose extremely high growth rates are generally recognized to be a result initially of foreign direct investment in export manufacturing.

That migrations are patterned is further reflected in the figures on the US share of global immigration. Though inadequate, the available evidence compiled by the United Nations Demographic Yearbook and World Population Prospects shows that in the mid-1980s the United States received about 19 percent of global emigration. This figure is derived from data on permanent settlement, which excludes illegal immigration and unofficial refugee flows between countries, a growing category. A breakdown by region and country of origin points to a distinct patterning. The US received 27 percent of total Asian emigration, but 81.5 percent of all Korean emigration and almost 100 percent of emigration from the Philippines. It received 70 percent of Caribbean emigration, but almost 100 percent of emigration from the Dominican Republic and Jamaica and 62 percent from Haiti. And it received 19.5 percent of all emigration from Central America, but 52 percent of emigration from El Salvador, the country with the greatest US involvement in the region.

On a more conceptual level one could generalize these tendencies and posit that immigration flows take place within systems and that these systems can be specified in a variety of ways. The type of economic specification contained in this particular paper represents but one of several possibilities. However, in other cases, the system within which immigration takes place is to be specified 
in political or ethnic terms. One could ask, for example, if there are systemic linkages underlying the current Central European migrations to Germany and Austria. Rather than simply posit the push factor of poverty, unemployment and the general failure of socialism, we might inquire as to the existence of linkages which operate as bridges. Thus, before WWII both Berlin and Vienna were major receivers of large migrations from a vast Eastern region. Furthermore, these practices produced and reproduced migration systems as such. Finally, the aggressive campaign during the cold war years showing the West as a place where economic well being is the norm and well-paying jobs are easy to get, must also have had some effect in inducing people to migrate westward; a more accurate portrayal of conditions in the West might have deterred potential migrants beyond the absolutely convinced ones who can be seen as constituting a pent-up demand - in other words, beyond those that would have come at all costs. These historical and current conditions contain elements for specifying the systems within which the current Eastern migration to Germany and Austria take place.

The fact that there is a geopolitics of migration is suggested by some of the immigration patterns in Europe. Sixty percent of the foreign residents in the United Kingdom are from Asian or African countries which were former dominions or colonies; European immigration is rather low, and almost threefourth of these come from Ireland - also once a colony. There are almost no immigrants from such countries as Turkey or Yugoslavia which provide the largest share to Germany, for instance. On the other side of the coin, almost all immigrants from the Indian subcontinent and from the English Caribbean residing in Europe are in the United Kingdom.

Continuing along these lines, in the first ten years after WWII, the vast majority of "immigrants" to Germany were the 8 million displaced ethnic Germans that resettled there. Another major group were the 3 million who= came from the GDR before the Berlin Wall was erected in 1961. Almost all ethnic Germans went to Germany; and those that did not go to Germany went overseas. But also $86 \%$ of Greek immigrants in Europe reside in Germany, almost $80 \%$ of Turkish immigrants in Europe and $76 \%$ of Yugoslavs. Almost all Algerians residing in Europe are in France; and so are $86 \%$ of Tunisians and $61 \%$ of Moroccans. Almost all immigrants in Europe from overseas territories still under French control - such as the French Antilles, Tahiti, French Guyana - reside in France. But so do $84 \%$ of Portuguese and of Spaniards residing in Europe outside their country. France has a long history 
of recruiting/receiving migrant workers from these countries for its vineyards going back to the 1800 s.

The Netherlands and Belgium both received significant numbers of people from their former colonial empires. They also received foreign workers from labor exporting countries, such as Italy, Morocco and Turkey. Switzerland similarly receives workers from traditional labor exporting countries: Italy, Spain, Portugal, Yugoslavia and Turkey. All three countries originally organized the recruitment of these workers, until eventually a somewhat autonomous set of flows was in place. Sweden receives $93 \%$ of Finnish immigrants. Also in Sweden as in the other countries, there is a large expansion of the recruitment area to include workers from the traditional labor exporting countries on the Mediterranean.

As a given labor migration flow ages, it tends to become more diversified in terms of destination. It suggests that a certain autonomy from older colonial and neo-colonial bonds sets in. Immigrants from Italy and Spain are now distributed among several countries. Among Italian immigrants in Europe, onethird reside in Germany, 27\% in France, $24 \%$ in Switzerland, and 15\% in Belgium. The fact that it is still a limited diversity of destinations could be seen as signaling the presence of migration systems. On the other hand, more recent labor migrations reveal very high levels of geographic concentration. The largest single immigrant group in any of Europe's labor receiving countries today are the Turks, with 1.5 million in Germany.

It does seem, and the history of economic development supports this, that once an area becomes a significant emigration region it does not easily catch up in terms of development with those areas that emerge as labor importing areas, precisely because these have high growth, or at least relatively high growth, it seems that there is an accumulation of advantage. History suggests that this is an advantage which labor sending areas either a) cannot catch up with, and/or b) are structurally not going to be part of because the spatialization of growth is precisely characterized by this type of uneven development. One cannot be too rigid and mechanical about these generalizations. But it is clear that Italy and Ireland, even if now they receive immigrants, have for two centuries been labor exporters and this has not necessarily been a macro-economic advantage, even though individuals and localities may have benefitted.

The case of Japan is of interest here because it allows us to capture the intersection of economic internationalization and immigration in its inception 
and to do so in a country with a radically different history, culture and, to a lesser extent, economic organization from those of other advanced economies (For a more detailed account see Sassen 1993; Shank 1995). One of the areas where this difference is evident is in Japan's lack of an immigration history. Yet, though much later than most advanced economies, Japan now has a growing unauthorized immigrant workforce in low-wage, unskilled jobs in a context where Japanese youth are rejecting such jobs.

Why has this happened now rather than during the period of extremely rapid economic growth in the 1950s and 1960s when Japan experienced very sharp labor shortages? Japan is a major presence in a regional Asian economic system where it is the leading investor, foreign aid donor, and exporter of consumer goods (including cultural products). And while Japan is not quite ầ open to foreign firms as the US, there is a growing presence of such firms. Is the new immigration to Japan unrelated to these processes of internationalization? Elsewhere (1993) I have argued that the new immigration is part of the globalization of Japan's economy. This is easy to recognize in the case of foreign high-level manpower for the financial industry in Tokyo. It is less clearly so in the case of the new, mostly unauthorized immigration of manual workers employed in construction, manufacturing and low-wage jobs in services. this latter case internationalization a) provides a context within which bridges are built with the countries of origin of potential emigrants and b) contributes to make the Japanese economy more porous, particularly so in the case of large cities.

Yet the policy framework for immigration treats the flow of labor as the result of individual actions, particularly the individual's decision to migrate in search of better opportunities. Such a policy puts responsibility for immigration on the shoulders of immigrants. Policy commentary which speaks of an immigrant "influx" or "invasion" treats the receiving country as a passive agent; the causes for immigration appear to be fundamentally unconnected to past or current actions of receiving countries; immigration policy becomes a decision to be more or less benevolent in admitting immigrants. Absent from this understanding is the notion that the international activities of the governments or firms of receiving countries may have contributed to the formation of economic linkages with emigration countries, linkages that may function as bridges not only for capital but also for migration flows.

We are seeing the formation of similar migration processes in all major advanced economies. These are forming at a very specific juncture: what we 
could identify analytically as the intersection of processes of economic internationalization and labor market developments. Placing the formation of immigration flows and their continuation at this juncture allows us to see important parallels in advanced economies with significant differences in terms of history and culture. The parallels result from the condition of being global powers with strong economic presences in transnational zones of influence and from major processes of economic restructuring evident in all advanced economies in the 1980s. The differences stem in part from the specifics of each country's culture and history. In Japan we see the beginnings of processes which are longer-standing in the US and in Western Europe 29.

29 This paper is based on a book being prepared for the Twenties Century Fund. I thank the Fund for its support. 


\section{References Cited}

Aman, Jr. Alfred C. (1995) "A Global Perspective on Current Regulatory Reform: Rejection, Relocation, or Reinvention? Indiana Journal of Global Legal Studies Vol 2, pp. 429-464.

Bade, Klaus J. (ed). 1992. Deutsche im Ausland, Fremde in Deutschland: Migration in Geschichte und Gegenwart. Munich: C.H. Beck Verlag.

Baubock, Rainer. (1994). Transnational Citizenship: Memberships and Rights in International Migration. (Aldershot, England: Edward Elgar)

Bohning, W.R. and M.-L. Schloeter-Paredes (eds). 1994. Aid in place of Migration. Geneva: International Labor Office.

Bonacich, Edna, Lucie Cheng, Norma Chinchilla, Nora Hamilton, and Pa Ong (eds.). Global Production: The Apparel Industry in the Pacific Rim. Philadelphia: Temple University Press 1994.

Bose, Christine E. and Edna Acosta-Belen (eds). 1995. Women in the Latin American Development Process. Philadelphia: Temple University Press.

Carbonneau, Thomas (ed.) 1990. Lex Mercatoria and Arbitration. Dobbs Ferry, NY: Transnational Juris Publications.

Competition and Change. The Journal of Global Business and Political Economy. Vol. 1, nr. 1. (Harwood Academic Publishers).

Coombe, Rosemary J. "The Properties of Culture and the Politics of Possessing Identity: Native Claims in the Cultural Appropriation Controversy." The Canadian Journal of Law and Jurisprudence, Vol.VI, No. 2, July 1993, pp.249-85.

Cornelius, Wayne A., Philip L. Martin, and James F. Hollifield (eds) Controlling Immigration. A Global Perspective. Stanford: Standford University Press. 1994. 
Dezalay, Yves and Garth, Bryant. 1995. "Merchants of Law as Moral Entrepreneurs: Constructing International Justice from the Competition for Transnational Business Disputes." Law and Society Review, 29, no.1, pp.2764.

Drache, D. and M. Gertler (eds.). The New Era of Global Competition: State Policy and Market Power. Montreal: McGill-Queen's University Press, 1991.

Hollifield, James F. Immigrants, Markets, and States. Cambridge, Mass: Harvard University Press 1992.

Hugo, Graeme. 1995. "Indonesia's Migration Transition." Journal fur Entwicklungspolitik, XI, 3: 285-309.

Jessop, Robert. State Theory: Putting Capitalist States in Their Place. University Park: Pennsylvania State University Press, 1990.

Journal fur Entwicklungspolitik. Schwerpunkt: Migration. (Special Issue on Migration). Vol. XI, nr. 3, 1995. (Frankfurt: Brandes \& Apsel Verlag).

Paul L. Knox and Peter J. Taylor (eds). 1995. World Cities in a WorldSystem. Cambridge, UK: Cambridge University Press.

Mahler, Sarah. 1995. American Dreaming: Immigrant Life on the Margins. Princeton, NJ: Princeton University Press.

Massey, Douglas S. Joaquin Arango, Graeme Hugo, Ali Kouaouci, Adela Pellegrino and J. Edward Taylor. 1993. "Theories of International Migration: A Review and Appraisal." Population and Development Review, 19, 3: 431466.

Mitchell, Christopher "International Migration, International Relations and Foreign Policy." International Migration Review (Fall 1989).

Mittelman, James. (ed). Yearbook of International Political Economy. Vol. 9. Boulder, Colo.:Lynne Reiner Publishers. 1996.

Negri, Toni (1995) “A quoi sert encore 1'Etat." Pouvoirs Pouvoir, Vol. 2526 of Futur Anterieur, pp.135-152. (Paris: L'Harmattan). 
Reimers, David M. (1983)."An unintended reform: The 1965 Immigration Act and Third World Immigration to the US" Journal of American Ethnic History 3 (Fall): 9-28.

Rosen, Fred and Deidre McFadyen (eds) 1995. Free Trade and Economic Restructuring in Latin America. (A NACLA Reader). New York: Monthly Review Press.

Salacuse, Jeswald.1991. Making Global Deals: Negotiating in the International Marketplace. Boston: Houghton Mifflin.

Sassen, Saskia. (1996) On Governing the Global Economy. The 1995 Leonard Hastings Schoff Memorial Lectures delivered at Columbia University, to be published by Columbia University Press.

- (1996a) Immigrants and Refugees: A European Dilemma? Frankfuit. Fischer Verlag.

- (In progress) Immigration Policy in a Global Economy. Under preparation for The Twentieth Century Fund.

Shank, G. (ed.) Japan Enters the 21st Century. A Special Issue of Social Justice. Vol. 21, number 2 (Summer) 1994.

Sinclair, Timothy J. 1994. "Passing Judgement: credit rating processes as regulatory mechanisms of governance in the emerging world order." Reviews of International Political Economy 1: 1 (Spring): 133-159.

Soysal, Yasmin. 1994. Limits of Citizenship. Chicago: University of Chicago Press.

Thranhardt, Dietrich (ed.) 1992. Europe: A New Immigration Continent. Hamburg: Lit Verlag.

Trubek, David M., Yves Dezalay, Ruth Buchanan, John R. Davis. "Global Restructuring and the Law: the Internationalization of Legal Fields and Creation of Transnational Arenas." Working Paper Series on the Political Economy of Legal Change. N. 1. Madison, Wisconsin: Global Studies Research Program, University of Wisconsin. 
Weil, Patrick. 1991. La France et ses étrangers. Paris: Calmann-Lévy.

Weiner, Myron. 1995. The Global Migration Crisis. New York: Harper Collins.

Zolberg, Aristide R. 1990. "The Roots of US Refugee Policy." In R. Tucker, Charles B. Keely, and Wrigley (eds) Immigration and US Foreign Policy. Boulder, Co: Westview Press. 


\section{Biographical Note}

SASKIA SASSEN is a Professor in the Department of Urban Planning and at the School of International and Public Affairs at Columbia University. She is the author of The Mobility of Labor and Capital: A Study in International Investment and Labor Flow (Cambridge University Press 1988), The Global City: New York, London, Tokyo (Princeton University Press 1991), and Cities in a World Economy (Pine Forge/Sage 1994). She has recentily completed Immigrants and Refugees: A European Dilemma for Fischer Verlag in Germany, due out in September 1996. She has received a grant from the Twentieth Century Fund to write a book about "Immigration Policy in $\mathbf{a}$ World Economy" and has begun a new five year research project on Governance and Accountability in a World Economy. 


\section{Jean Monnet Chair Papers}

\section{European University Institute, Florence}

\section{CHRISTOPH BERTRAM/Sir}

JULIAN BULLARD/

LORD COCKFIELD/ Sir DAVID

HANNAY/MICHAEL PALMER

Power and Plenty? From the Internal Market to Political and Security Cooperation in Europe, April 1991, pp. 73

\section{ROBERT GILPIN}

The Transformation of the International Political Economy, April 1991, pp.27

3. EDMOND MALINVAUD Macroeconomic Research and European Policy Formation April 1991, pp. 58

\section{SERGIO ROMANO}

Soviet Policy and Europe Since Gorbachev, April 1991, pp. 25

\section{BERNT VON STADEN}

The Politics of European Integration, April 1991, pp. 33

6. HELGA HAFTENDORN European Security Cooperation and the Atlantic Alliance, July 1991, pp. 42

7. THOMAS ANDERSSON/STAFFAN BURENSTAM LINDER Europe and the East Asian Agenda, October 1991, pp. 87
8. ROGER G. NOLL The Economics and Politics of Deregulation, October 1991, pp. 89

9. ROBERT TRIFFIN IMS International Monetary System - or Scandal?, March 1992, pp. 49

10. EGON BAHR

From Western Europe to Europe, June 1992, pp. 42

\section{HELGE HVEEM}

The European Economic Area and the Nordic Countries - End Station or Transition to EC Membership?, June 1992, pp. 21

12. ERIC STEIN

Post-communist Constitutionmaking: Confessions of a Comparatist (Part I), August 1992, pp. 63

\section{CAROLE FINK} 1922/23 From Illusion to Disillusion, October 1992, pp. 19

\section{LOUIS H. ORZACK} International Authority and Professions. The State Beyond The Nation-State, November 1992, pp. 47 
15. VLADIMIR M. KOLLONTAI

Economic Reform in Russia

November 1992, pp. 43

\section{RYUTARO KOMIYA}

Japan's Comparative Advantage in the Machinery Industry:

Industrial Organization and

Technological Progress,

October 1993, pp. 60

17. GiUliano Amato

Problems of Governance - Italy and Europe: A Personal

Perspective,

October 1994, pp. 39

18. JEREMY RICHARDSON

The Market for Political

Activism: Interest Groups as a

Challenge to Political Parties,

November 1994, pp. 37

19. RICHARD B. STEWART

Markets versus Environment?, January 1995, pp. 53

\section{JOHN GERARD RUGGIE}

At Home Abroad, Abroad at

Home: International Liberaliza-

tion and Domestic Stability in the

New World Economy,

February 1995, pp. 64

\section{DAVID VOGEL}

The Relationship Between Environmental and Consumer Regulation and International Trade, February 1995, pp. 44

22. JOHN WILLIAMSON

Proto-EMU as an Alternative to Maastricht

March 1995, pp. 20
23. THOMAS C. HELLER

Joint Implementation and the Path to a Climate Change Regime

March 1995, pp. 49

24. NORMAN SCHOFIELD

Modelling Political Order in

Representative Democracies

June 1995, pp. 38

25. VOJIN DIMITRIEVIC

The Fate of Non-Members of Dominant Nations in PostCommunist European Countries June 1995, pp. 34

\section{HORST SIEBERT}

Eastern Germany in the Fifth Year. Investment Hammering in the Basement?

September 1995, pp. 45

27. CAROL HARLOW

Codification of EC

Administrative Procedures?

Fitting the Foot to the Shoe or the Shoe to the Foot

September 1995, pp. 34

28. FRITZW. SCHARPF

Negative and Positive Integration in the Political Economy of

European Welfare States

November 1995, pp. 44

29. VINCENT WRIGHT

Industrial and Banking

Privatization in Western Europe:

Some Public Policy Paradoxes

November 1995 , pp. 40 
30. ROBERT O. KEOHANE

Local Commons and Global

Environmental Interdependence:

Tragedy of the Commons or

Opportunity for Institutions?

November 1995, pp. 21

\section{SABINo CASSESE}

The Difficult Profession of

Minister of Public

Administration

December 1995, pp. 31

32. MANCUR OLSON JR.

The Varieties of Eurosclerosis:

The Rise and Decline of Nations since 1982

December 1995, pp. 37

\section{ROD A.W. RHODES}

Towards a Postmodern Public

Administration: Epoch,

Epistemology or Narrative?

December 1995, pp. 49

34. MARTIN SHAPIRO

Independent Agencies: US and

EU

April 1996, pp. 31

\section{SASKIA SASSEN}

The De-Facto Transnationalizing of Immigration Policy

April 1996, pp. 36 
